\title{
Our Experience with Maxillectomies: A Retrospective Decade Study
}

${ }^{1}$ MK Rajasekar, ${ }^{2}$ Vivek Mariappan, ${ }^{3}$ Narendrakumar Veerasigamani

\section{ABSTRACT}

Objective: The aim of the study is to evaluate the age, sex, site of lesion, histopathological diagnosis, and recurrence rate of the maxillectomy patients.

Materials and methods: A retrospective study was done in 42 patients, who underwent maxillectomy for malignant growth of the nose and paranasal sinuses from 2006 to 2015 at our center.

Results: The most common age group is 55 to 65 years (73.8), with male predominance (66.7\%). Among symptoms prevalent is nasal obstruction (47\%). Maxillary sinus is the most common site of origin $(61.9 \%)$. Squamous cell carcinoma is the most common histopathological diagnosis (52.4\%) and recurrence rate is $16 \%$.

Conclusion: Exact clearance, reconstruction, postoperative care, and perfect teamwork play a vital role. Thus, successful outcome of maxillectomy is multifactorial.

Keywords: Maxillectomy, Paranasal tumors, Reconstruction, Squamous cell carcinoma.

How to cite this article: Rajasekar MK, Mariappan V, Veerasigamani N. Our Experience with Maxillectomies: A Retrospective Decade Study. Clin Rhinol An Int J 2017;10(2):58-61.

\section{Source of support: Nil}

Conflict of interest: None

\section{INTRODUCTION}

Total maxillectomy refers to surgical resection of the entire maxilla including the floor and medial wall of the orbit and the ethmoid sinuses, which may be extended to include orbital exenteration and sphenoidectomy, and resection of the pterygoid plates. It is generally indicated for malignancy involving the maxillary sinus and maxillary bone. Liston performed the first recorded maxillectomy in 1841 on a 21-year-old patient with nasopharyngeal angiofibroma. ${ }^{1}$ Incidence of nasal cavity and paranasal sinus malignancies constitutes $1 \%$ of all the

${ }^{1}$ Professor, ${ }^{2}$ Senior Resident, ${ }^{3}$ Ex-Resident

1,3 Department of ENT, Madras Medical College, Chennai, Tamil Nadu, India

2Department of ENT, Government Medical College, Omandurar Government Estate, Chennai, Tamil Nadu, India

Corresponding Author: MK Rajasekar, Professor, Department of ENT, Madras Medical College, Chennai, Tamil Nadu, India Phone: +919176054266, e-mail: stanvivek@gmail.com malignancies in the body and about $3 \%$ in the aerodigestive tract, and they often do not cause symptoms until they have expanded to a significant size or have extended through the bony confines of the sinus cavity; thus, tumors tend to present at a more advanced stage. ${ }^{2}$

Early diagnosis is possible only by the role of radiological evaluation, which helps to stage the disease and plan the treatment protocol. Sarcoma and other noncarcinomas occur at a younger age than carcinoma. ${ }^{3}$ Adenocarcinoma and squamous cell carcinoma are the most histologic types of sinonasal tumors, in which compared with squamous cell carcinoma, adenocarcinoma has more disease-specific survival and recurrence-free survival. ${ }^{4}$

\section{MATERIALS AND METHODS}

A retrospective study was done in 42 patients, who underwent maxillectomy for malignant growth of the nose and paranasal sinuses at Madras Medical College from 2006 to 2015. Patients who were not willing for the study and without regular follow-ups were excluded from the study. Age, sex, site of lesion, histopathological diagnosis, and recurrence rate were taken into account and statistically analyzed.

\section{RESULTS}

Considering the age group, majority were between the fifth and sixth decades of life (Tables 1 and 2); of these $28(66.7 \%)$ were males and $14(33.3 \%)$ were females (Tables 3 and 4). Among symptoms, most common was nasal obstruction (47\%) (Graph 1). Most common histopathological diagnosis was squamous cell carcinoma (52.4\%) followed by adenocarcinoma (19\%) (Graph 2) with the recurrence rate of $16 \%$. On comparing sex vs histopathological diagnosis, squamous cell carcinoma was common in males and adenocarcinoma in females (Tables 3 and 4). Maxillary sinus (61.9\%) was the most common site of origin (Graph 3), in which squamous cell carcinoma was the most common histopathological diagnosis (Tables 5 and 6).

\section{DISCUSSION}

Sinonasal malignancy usually presents as advanced disease as early diagnosis is difficult. The mainstay of the treatment is radical surgical excision. ${ }^{5}$ Among the site 
Our Experience with Maxillectomies: A Retrospective Decade Study

Table 1: Age vs histopathological diagnosis (cross-tab)

\begin{tabular}{|c|c|c|c|c|c|c|c|}
\hline & & & \multicolumn{5}{|c|}{ Histopathological diagnosis } \\
\hline & & & $\begin{array}{l}\text { Squamous cell } \\
\text { carcinoma }\end{array}$ & Adenocarcinoma & $\begin{array}{l}\text { Adenocystic } \\
\text { carcinoma }\end{array}$ & Others & Total \\
\hline \multirow[t]{8}{*}{ Age (years) } & $20-35$ & Count & 1 & 0 & 0 & 0 & 1 \\
\hline & & $\%$ of total & 2.4 & 0 & 0 & 0 & 2.4 \\
\hline & $36-50$ & Count & 2 & 0 & 0 & 0 & 2 \\
\hline & & $\%$ of total & 4.8 & 0 & 0 & 0 & 4.8 \\
\hline & $51-65$ & Count & 19 & 8 & 4 & 0 & 31 \\
\hline & & $\%$ of total & 45.2 & 19.0 & 9.5 & 0 & 73.8 \\
\hline & $66-80$ & Count & 0 & 0 & 3 & 5 & 8 \\
\hline & & $\%$ of total & 0 & 0 & 7.1 & 11.9 & 19.0 \\
\hline \multirow[t]{2}{*}{ Total } & & Count & 22 & 8 & 7 & 5 & 42 \\
\hline & & $\%$ of total & 52.4 & 19.0 & 16.7 & 11.9 & 100.0 \\
\hline
\end{tabular}

Table 2: Age vs histopathological diagnosis (Chi-square test)

\begin{tabular}{llll}
\hline & Value & $d f$ & Asymp. sig. (two-sided) \\
\hline Pearson Chi-square & $32.894^{\mathrm{a}}$ & 9 & 0 \\
Likelihood ratio & 34.108 & 9 & 0 \\
Linear-by-linear association & 18.995 & 1 & 0 \\
No. of valid cases & 42 & & \\
\hline
\end{tabular}

${ }^{\mathrm{a}}$ Thirteen cells (81.3\%) have expected count less than 5 . The minimum expected count is 0.12 ; df: degree of freedom

Table 3: Sex vs histopathological diagnosis (cross-tab)

\begin{tabular}{|c|c|c|c|c|c|c|c|}
\hline & & & \multicolumn{5}{|c|}{ Histopathological diagnosis } \\
\hline & & & $\begin{array}{l}\text { Squamous cell } \\
\text { carcinoma }\end{array}$ & Adenocarcinoma & $\begin{array}{l}\text { Adenocystic } \\
\text { carcinoma }\end{array}$ & Others & Total \\
\hline \multirow[t]{4}{*}{ Age (years) } & Male & Count & 22 & 6 & 0 & 0 & 28 \\
\hline & & $\%$ of total & 52.4 & 14.3 & $0 \%$ & 0 & 66.7 \\
\hline & Female & Count & 0 & 2 & 7 & 5 & 14 \\
\hline & & $\%$ of total & 0 & 4.8 & 16.7 & 11.9 & 33.3 \\
\hline \multirow[t]{2}{*}{ Total } & & Count & 22 & 8 & 7 & 5 & 42 \\
\hline & & $\%$ of total & 52 & 19.0 & 16. & 11.9 & 100.0 \\
\hline
\end{tabular}

Table 4: Sex vs histopathological diagnosis (Chi-square test)

\begin{tabular}{llll}
\hline & Value & $d f$ & Asymp. sig. (two-sided) \\
\hline Pearson Chi-square & $32.250^{\text {a }}$ & 3 & 0 \\
Likelihood ratio & 44.470 & 3 & 0 \\
Linear-by-linear association & 31.622 & 1 & 0 \\
No. of valid cases & 42 & & \\
\hline
\end{tabular}

aFive cells (62.5\%) have expected count less than 5. The minimum expected count is 1.67; df: degree of freedom

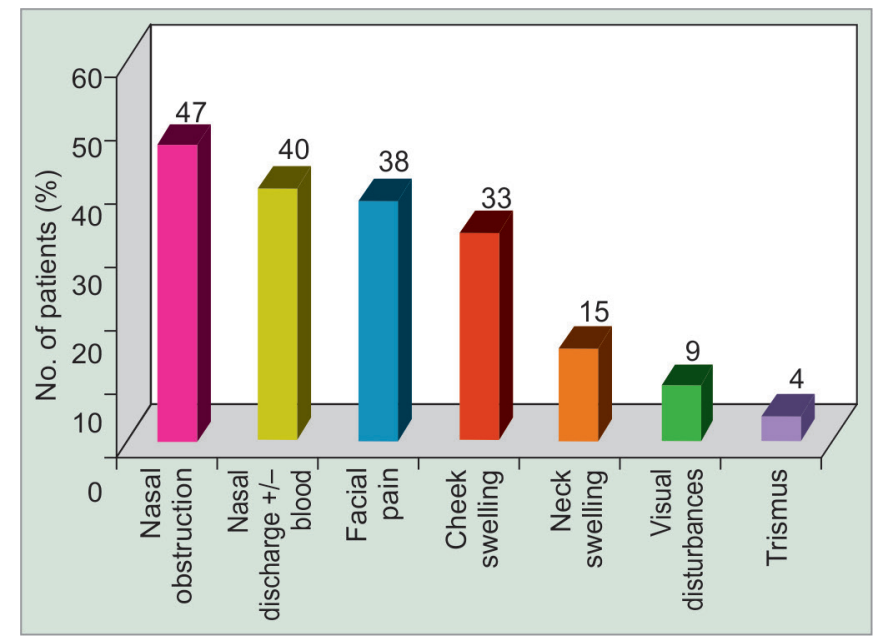

Graph 1: Presenting symptoms

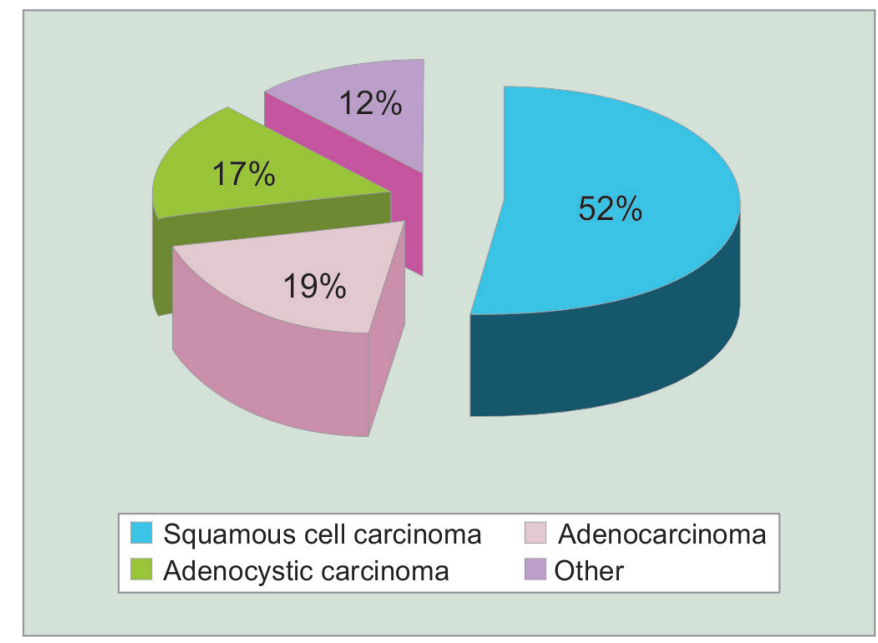

Graph 2: Histopathological diagnosis 


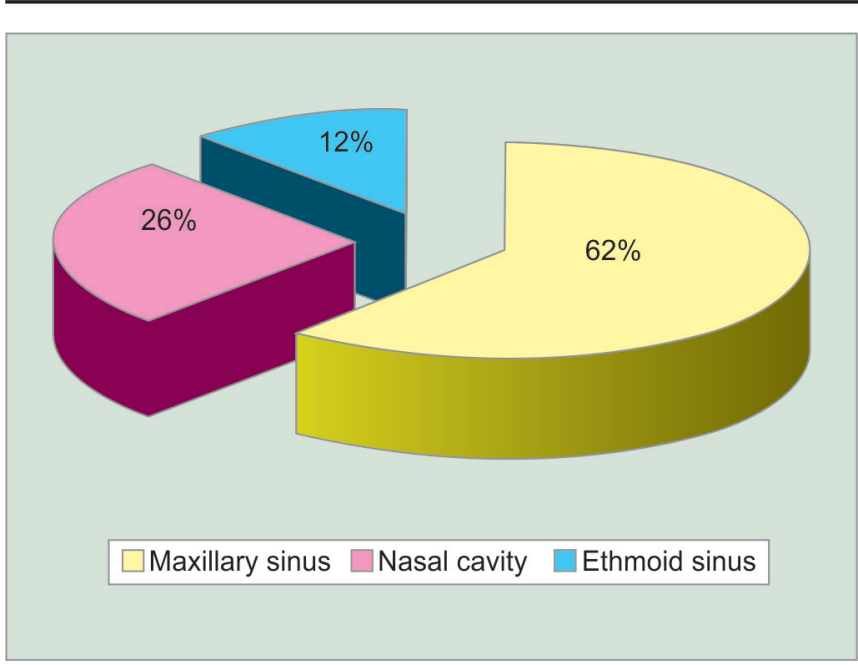

Graph 3: Site of origin

of origin, most common is the maxillary sinus, followed by nasal walls and ethmoid sinuses and very few from frontal and sphenoid sinuses. ${ }^{6}$ There are many approaches to the maxillary region but the most commonly used approaches are Weber-Ferguson incision and midface deglowing incision. ${ }^{7}$ The classical Weber-Ferguson incision follows the natural skin crease and provides excellent exposure, minimal scarring, and clearance of the tumor with safe margins. ${ }^{8}$ Depending on the staging of the tumor, suitable modifications of classical incisions are:

- Lateral rhinotomy

- Weber-Ferguson incision

- Weber-Ferguson incision with Lynch extension

- Weber-Ferguson incision with lateral subciliary extension
- Weber-Ferguson incision with subciliary and supraciliary extension

Bidra et $\mathrm{al}^{9}$ identified six criteria for the classification of maxillectomy defects. These criteria were:

1. Dental status

2. Oroantral/nasal communication status

3. Soft palate and other contiguous structure involvement

4. Superior-inferior extent

5. Anteroposterior extent

6. Medial-lateral extent of the defect

There are many classification systems for maxillectomy surgeries, but the most reliable one was by Durrani et $\mathrm{al}^{10}$ classification.

- Alveolectomy

- Subtotal maxillectomy

- Total maxillectomy

- Radical maxillectomy

- Complete maxillectomy.

The extent of the tumor and invasion of the surrounding structures determine the surgery plan. The primary treatment is surgical resection and postoperative radiation for adverse parameters. ${ }^{6}$

The periorbitum is a barrier against invasion into orbit, but once the tumor has infiltrated this periosteum, it gains access to a space that lacks barriers to check local tumor spread. It is important to decide the difference between erosion of the bony orbital wall, infiltration of the periosteum, and deeper invasion of the orbital soft tissues. The term "orbital exenteration" is the complete removal of the contents of the orbit including the eyelids, whereas "orbital clearance" is a surgical procedure in which the

Table 5: Site of origin vs histopathological diagnosis (cross-tab)

\begin{tabular}{|c|c|c|c|c|c|c|c|}
\hline & & & \multicolumn{5}{|c|}{ Histopathological diagnosis } \\
\hline & & & $\begin{array}{l}\text { Squamous cell } \\
\text { carcinoma }\end{array}$ & Adenocarcinoma & $\begin{array}{l}\text { Adenocystic } \\
\text { carcinoma }\end{array}$ & Others & Total \\
\hline \multirow[t]{6}{*}{ Site of origin } & Maxillary sinus & Count & 22 & 4 & 0 & 0 & 26 \\
\hline & & $\%$ of total & 52.4 & 9.5 & 0 & 0 & 61.9 \\
\hline & Nasal cavity & Count & 0 & 4 & 7 & 0 & 11 \\
\hline & & $\%$ of total & 0 & 9.5 & 16.7 & 0 & 26.2 \\
\hline & Ethmoid sinus & Count & 0 & 0 & 0 & 5 & 5 \\
\hline & & $\%$ of total & 0 & 0 & 0 & 11.9 & 11.9 \\
\hline \multirow[t]{2}{*}{ Total } & & Count & 22 & 8 & 7 & 5 & 42 \\
\hline & & $\%$ of total & 52.4 & 19.0 & 16.7 & 11.9 & 100.0 \\
\hline
\end{tabular}

HPE: Histopathological examination

Table 6: Site of origin vs histopathological diagnosis (Chi-square test)

\begin{tabular}{llll}
\hline & Value & $d f$ & Asymp. sig. (two-sided) \\
\hline Pearson Chi-square & $73.133^{\mathrm{a}}$ & 6 & 0 \\
Likelihood ratio & 64.605 & 6 & 0 \\
Linear-by-linear association & 35.957 & 1 & 0 \\
No. of valid cases & 42 & & \\
\hline
\end{tabular}

aTen cells (83.3\%) have expected count less than 5. The minimum expected count is 0.60; HPE: Histopathological examination; df: degree of freedom 
globe, muscles, fat, and periorbita are removed, while the lids and the palpebral conjunctiva are preserved. ${ }^{5}$

Iannetti et $\mathrm{al}^{11}$ have described three stages of orbital invasion:

1. Grade I-erosion or destruction of the medial orbital wall

2. Grade II-extraconal invasion of the periorbital fat

3. Grade III-invasion of the medial rectus muscle, optic nerve, ocular bulb, or the skin overlying the eyelid

Orbital preservation can be done when the periorbita is not infiltrated by the tumor. Grade III orbital invasion warrants orbital clearance or exenteration.

Patients with postoperative radiotherapy treatment may develop trismus, dryness of the oral mucosa, hypernasality of speech, regurgitation of fluids, and difficulty with obturator insertion. Thus, postoperative radiotherapy is the best predictor of quality of life in postmaxillectomy patients. ${ }^{12}$

Rehabilitation of the maxillectomy patients is done by reconstruction of maxillary defects with best obturator prosthesis to restore a maximum quality of life. ${ }^{13}$ The goal of reconstruction should be to support orbital contents or to treat the exenterated orbit cosmetically, to maintain a patency between nasal airway and oronasal separation to provide good mastication and speech, and to restore a symmetric facial contour with the other side of the face. Reconstruction is important because an individual's intentions to consume food are influenced not only by hunger and physiological mechanisms but also by social and cultural factors. ${ }^{14}$ Prosthesis is a good temporary solution by allowing time to rule out a recurrence or while adjuvant therapy is given since multistaged reconstruction might delay timely treatment and also radiation-associated tissue changes will compromise the final reconstructive result. In our study, we used guttapercha prosthesis for reconstruction. ${ }^{15}$

\section{CONCLUSION}

The outcome of the maxillectomy depends upon many factors like: (1) histology of the tumor, (2) tumor stage, (3) feasibility of a complete surgical resection, (4) the patient's underlying medical condition, (5) associated treatment risks and morbidity, (6) reconstructive options for the restoration of form and function. Surgical plan should be done by assessing whether to include soft tissues in en bloc resection, proper approach thereby providing adequate exposure with good cosmetic results, and performing best reconstructions. ${ }^{16}$ Management of such case is a challenging tool as it is a multimodality treatment that involves oncosurgeons, prosthodontist, radiation oncologist, and speech therapist. ${ }^{5}$

\section{REFERENCES}

1. Myhre M, Michaels L. Nasopharyngeal angiofibroma treated in 1841 by maxillectomy. J Otolaryngol 1987 Dec;16(6): 390-392.

2. Yoskovitch A, Braverman I, Nachtigal D, Frenkiel S, Rochon L, Black MJ. Sinonasal Schneiderian papilloma. J Otolaryngol 1998 Jun;27(3):122-126.

3. Weber AL, Stanton AC. Malignant tumors of the paranasal sinuses: radiological, clinical and histopathologic evaluation of 200 cases. Head Neck Surg 1984 Jan-Feb;6(3):761-776.

4. Ganly I, Patel SG, Singh B, Kraus DH, Bridger PG, Cantu G, Cheesman A, De Sa G, Donald P, Fliss DM, et al. Craniofacial resection for malignant paranasal sinus tumors: report of an international collaborative study. Head Neck 2005 Jul;27(7):575-584.

5. Lekawale H, Chitharanjan A. Total maxillectomy with orbital clearance for squamous cell carcinoma of maxilla - our experience with two cases and literature review. Indian J Appl Res 2012 Oct;2(3):149-152.

6. Mazlina S, Putra SH, Shiraz MA, Hazim MY, Roszalina R, Abdul AR. Maxillary Sinus tumors - a review of twenty-nine patients treated by maxillectomy approach. Med J Malaysia 2006 Aug;61(3):284-287.

7. Rajasekhar G, Gopal Vura N, Sudhir R, Dhanala S, Alwala AM. Versatility of Dieffenbach's modification of Weber Fergusson's approach for treatment of maxillary pathologies. J Maxillofac Oral Surg 2012 Dec;11(4):416-419.

8. Bhavana K, Tyagi I, Ramani MK. Modified incision for maxillectomy: our experience. Indian J Otolaryngol Head Neck Surg 2012 Jun;64(2):184-187.

9. Bidra AS, Jacob RF, Taylor TD. Classification of maxillectomy defects: a systemic review and criteria necessary for a universal description. J Prosthet Dent 2012 Apr;107(4): 261-270.

10. Durrani Z, Hussain SG, Alam SA. A study of classification systems for maxillectomy defects. J Pak Prosthodont 2013;1(2):117-124.

11. Iannetti G, Valentini V, Rinna C, Ventucci E, Marianetti TM. Ethmoido-orbital tumors: our experience. J Craniofac Surg 2005 Nov;16(6):1085-1091.

12. Genden EM, Okay D, Stepp MT, Rezaee RP, Mojica JS, Buchbinder D, Urken ML. Comparison of functional and qualityof-life outcomes in patients with and without palate maxillary reconstruction: a preliminary report. Arch Otolaryngol Head Neck Surg 2003 Jul;129(7):775-780.

13. Lethaus B, Lie N, De Beer F. Surgical and prosthetic reconsiderations in patients with maxillectomy. J Oral Rehabil 2010;37:138-142.

14. Andrades P, Militsakh O, Hanasono MM, Rieger J, Rosenthal EL. Current strategies in reconstruction of maxillectomy defects. Arch Otolaryngol Head Neck Surg 2011 Aug;137(8):806-812.

15. De la Rie S, Noordenbos G, Donker M, van Furth E. The patient's view on quality of life and eating disorders. Int J Eat Disord 2007 Jan;40(1):13-20.

16. Shah, J. Nasal cavity and paranasal sinuses. In: Head and neck surgery diagnostic approaches, therapeutic decisions, surgical techniques and result of treatment. 2 nd ed. London: Mosby-Wolfe; 1996. p. 53-74. 